\title{
Comparative Efficacy of Different Fungicides under Open and Protected Conditions Against Pea Powdery Mildew (Erysiphe pisi) in Cold Desert Zone of Himachal Pradesh
}

\author{
R. S. Jarial ${ }^{1 *}$, Kumud Jarial ${ }^{2}$, Dharmesh Gupta ${ }^{3}$ and C. L. Sharma ${ }^{4}$
}

${ }^{1 \& 2}$ College of Horticulture and Forestry, Dr. Y. S. Parmar, UHF, Neri, Hamirpur, Himachal Pradesh (177 001), India ${ }^{3}$ Dept. of Plant Pathology, Dr. Y. S. Parmar University of Horticulture and Forestry, Nauni, Solan,Himachal Pradesh (173 230), India ${ }^{4}$ Dept. of Fruit Science, Dr. Y. S. Parmar University of Horticulture and Forestry, Nauni, Solan, Himachal Pradesh1(173 230), India

\section{Article History}

Manuscript No. AR1361

Received in $30^{\text {th }}$ March, 2015

Received in revised form $26^{\text {th }}$ September, 2015

Accepted in final form $6^{\text {th }}$ October, 2015

\section{Correspondence to}

${ }^{*}$ E-mail: rsjarial@rediffmail.com

\section{Keywords}

Pea, powdery mildew, Erysiphe pisi, fungicides

\begin{abstract}
Pea is the principal off season vegetable crop of dry temperate zone of Himachal Pradesh. The crop becomes highly susceptible to powdery mildew (Erysiphe pisi) due to highly fluctuating climate and meager humidity during the cropping season in the valley, resulting in huge losses. Experiments were conducted during 2010 and 2011 cropping seasons as randomized block design at research farm of Dr.Y. S Parmar University Regional Horticultural Research Sub Station, Tabo, Spiti, Himachal Pradesh both under natural epiphytotic and protected conditions. Plants of variety Azad P1 were raised in thirty five plots of size $2 \times 2 \mathrm{~m}^{2}$. The seed was sown by broadcast method in all the plots. In all, six fungicides viz., Kitazin, Dimethomorph, Difenoconazole, Hexaconazole, Propiconazole and Carbendazim sprayed at 15 days interval starting from the first appearance of the disease symptoms were evaluated against the disease. It was found that the plots sprayed with hexaconazole exhibited minimum disease severity (35.50 and $16.50 \%$, respectively) and maximum disease control (63.95 and $81.03 \%$, respectively) pooled for two years both under natural and protected conditions. As far as pod yield was concerned, it was found to be inversely proportional to disease levels, being maximum in the plots with minimum disease severity and vice versa under both conditions in 2010 and 2011 crop seasons. The apparent infection rates pooled for two years varied from 0.04 to 0.12 unit $^{-1}$ day $^{-1}$ in plots sprayed with different fungicides which was quite low in comparison to untreated control plots exhibiting apparent infection rates of 0.38 and 0.30 unit $^{-1}$ day $^{-1}$ under natural and protected conditions, respectively.
\end{abstract}

\section{Introduction}

Pea (Pisum sativum L.) belonging to family leguminosae is one of the important vegetable crops of subtropical and temparate areas. The seeds of the crop are consumed as a vegetable and are used as a delicacy with other food stuff (Yawalkar, 1992). In Himachal Pradesh, the crop is raised as a winter vegetable in sub tropical and sub temperate zones while, in temperate zone it is raised as an off season vegetable which fetches good price in the market and brings lucrative returns to the growers. Spiti valley of Himachal Pradesh falls under dry temperate zone of the state and the valley is a typical mountain desert area with an average annual rainfall of only $170 \mathrm{~mm}$ (Kapadia, 1999). The treacherous wealth in Spiti valley permits farmers to grow only peas in addition to apple and naked barley in the region, as the cropping season is only for five months. The financial position of the people mainly depends on pea and apple cultivation. The crop is grown as an off season vegetable in the zone because that is the only time favourable for the cultivation of the crop in the zone. From May to mid Oct, it seldom rains and the mercury level does not exceed $30^{\circ} \mathrm{C}$ and never falls below $15^{\circ} \mathrm{C}$. There is little or no rain in monsoons. The climate remains dry and the days are hot and nights are extremely cold (Anonymous, 2015). As the climate in the valley is highly fluctuating and humidity is meagre during the cropping season, the crop becomes highly susceptible to powdery mildew (Erysiphe pisi) resulting in huge crop losses. Additionally, due to short term cropping period available to the growers, the crop is generally raised through broadcast method of cultivation in the zone which further increases the chances of disease development. Chemical control of the disease has been reported to be effective if applied at proper 
time (Jarial and Sharma, 2005) and different chemicals have been tested for their efficacy against the disease from time to time (Kotasathane, 1975., Upadhayay and Gupta, 1994., Kapoor and Sugha, 1995; Jarial and Sharma, 2005). But, the effect of fungicides on rate of disease development under protected and open conditions in the cold desert zone has not been studied so far. Keeping in view the seriousness of the disease in the region, present investigations were undertaken with an objective to compare the efficacy of different chemicals under open and protected conditions on disease intensity and rate of its development.

\section{Materials and Methods}

Experiments were conducted during the summer months of 2010 and 2011 as randomized block design at research farm of Dr. Y.S.Parmar University Regional Horticultural Research Sub Station, Tabo, Spiti, Himachal Pradesh both under natural epiphytotic and protected conditions. Plants of variety Azad $\mathrm{P} 1$ were raised in thirty five plots of size $2 \times 2 \mathrm{~m}^{2}$. The seed was sown by broadcast method in all the plots. In all, six systemic fungicides viz., Kitazin 48\% EC, Demethomorph 50\% WP, Difenoconazole 25\% EC, Hexaconazole 5\% EC, Propiconazole 25\% EC and Carbendazim 50\% WP were evaluated against the disease. All the fungicides were sprayed four times at a concentration of $0.05 \%$ at 15 days interval starting from the first appearance of the disease symptoms.Untreated plots served as check during both the years. All the treatments were replicated five times. Observations were recorded in terms of disease severity based on the scale given by Munjal et al. (1963) with slight modifications at weekly intervals till the disease in control plots approached at almost $100 \%$ level. The data were presented as disease index (\%) calculated as per the formula of Mc Kinney (1923). Data for two years were pooled and analyzed as per the statistical methods given by Gomez and Gomez (1984). Further, disease control (\%) was calculated in the pooled data as per the following formula:

$$
\text { Disease control }(\%)=\mathrm{C}-\mathrm{T} / \mathrm{C} \times 100
$$

Where,

$\mathrm{C}$ is the disease severity (\%) in control plot

$\mathrm{T}$ is the disease severity (\%) in fungicide treated plot

Additionally, apparent infection rate $\left(\right.$ unit $\left.^{-1} \mathrm{day}^{-1}\right)$ was also calculated as per the formula given by Van der Plank (1963)

$$
\mathrm{r}=1 /\left(\mathrm{t}_{2}-\mathrm{t}_{1}\right) \times \ln \left\{\mathrm{x}_{2}\left(1-\mathrm{x}_{1} / \mathrm{x}_{1}\left(1-\mathrm{x}_{2}\right)\right\}\right.
$$

Where,

$t_{2}-t_{1}$ is the time interval between two data recording dates

$\mathrm{x}_{1}$ is the disease proportion at time $\mathrm{t}_{1}$

\section{Results and Discussion}

It can be inferred from the data presented in (Table 1). that mean disease severity was significantly minimum $36.00 \%$ in 2010 and $35.00 \%$ during 2011 in the plots sprayed with

\begin{tabular}{|c|c|c|c|c|c|c|c|c|c|}
\hline \multirow[t]{2}{*}{ Treatments } & \multirow[t]{2}{*}{$\begin{array}{c}\text { Concentrations } \\
(\%)\end{array}$} & \multicolumn{3}{|c|}{$\begin{array}{c}\text { Mean disease severity (\%) } \\
\text { under natural epiphytotic } \\
\text { conditions }\end{array}$} & \multirow[t]{2}{*}{$\begin{array}{c}\text { Disease } \\
\text { control (\%) }\end{array}$} & \multicolumn{3}{|c|}{$\begin{array}{c}\text { Mean disease severity (\%) } \\
\text { under protected } \\
\text { conditions }\end{array}$} & \multirow[t]{2}{*}{$\begin{array}{c}\text { Disease } \\
\text { control (\%) }\end{array}$} \\
\hline & & 2010 & 2011 & Pooled & & 2010 & 2011 & Pooled & \\
\hline Kitazin $48 \%$ EC & 0.05 & $\begin{array}{c}55.33 \\
(48.07)\end{array}$ & $\begin{array}{c}52.66 \\
(46.53)\end{array}$ & $\begin{array}{c}54.00 \\
(47.30)\end{array}$ & 45.17 & $\begin{array}{c}34.66 \\
(36.07)\end{array}$ & $\begin{array}{c}36.66 \\
(37.26)\end{array}$ & $\begin{array}{c}35.66 \\
(36.67)\end{array}$ & 59.01 \\
\hline Demethomorph 50\% WP & 0.05 & $\begin{array}{c}68.33 \\
(55.77)\end{array}$ & $\begin{array}{c}66.66 \\
(54.75)\end{array}$ & $\begin{array}{c}67.50 \\
(55.25)\end{array}$ & 31.47 & $\begin{array}{c}41.33 \\
(40.00)\end{array}$ & $\begin{array}{c}51.66 \\
(45.95)\end{array}$ & $\begin{array}{c}46.50 \\
(42.98)\end{array}$ & 46.55 \\
\hline Difenoconazole $25 \%$ EC & 0.05 & $\begin{array}{c}56.66 \\
(48.33)\end{array}$ & $\begin{array}{c}46.66 \\
(43.08)\end{array}$ & $\begin{array}{l}51.66 \\
(45.95)\end{array}$ & 47.55 & $\begin{array}{c}27.66 \\
(31.72)\end{array}$ & $\begin{array}{l}29.66 \\
(32.95)\end{array}$ & $\begin{array}{c}28.66 \\
(32.35)\end{array}$ & 67.06 \\
\hline Hexaconazole 5\% EC & 0.05 & $\begin{array}{l}36.00 \\
(36.86)\end{array}$ & $\begin{array}{l}35.00 \\
(36.27)\end{array}$ & $\begin{array}{l}35.50 \\
(36.57)\end{array}$ & 63.95 & $\begin{array}{c}15.33 \\
(22.98)\end{array}$ & $\begin{array}{l}17.66 \\
(24.75)\end{array}$ & $\begin{array}{l}16.50 \\
(23.88)\end{array}$ & 81.03 \\
\hline $\begin{array}{l}\text { Carbendazim } \\
50 \% \text { WP }\end{array}$ & 0.05 & $\begin{array}{c}41.33 \\
(40.00)\end{array}$ & $\begin{array}{c}41.66 \\
(40.19)\end{array}$ & $\begin{array}{c}41.50 \\
(40.11)\end{array}$ & 57.86 & $\begin{array}{c}26.66 \\
(31.09)\end{array}$ & $\begin{array}{l}22.66 \\
(28.62)\end{array}$ & $\begin{array}{c}24.66 \\
(29.77)\end{array}$ & 71.66 \\
\hline $\begin{array}{l}\text { Propiconazole } \\
25 \% \text { EC }\end{array}$ & 0.05 & $\begin{array}{c}45.66 \\
(42.51)\end{array}$ & $\begin{array}{c}51.66 \\
(45.95)\end{array}$ & $\begin{array}{c}48.66 \\
(44.23)\end{array}$ & 50.59 & $\begin{array}{c}31.33 \\
(34.03)\end{array}$ & $\begin{array}{l}40.00 \\
(36.65)\end{array}$ & $\begin{array}{c}35.66 \\
(36.66)\end{array}$ & 59.01 \\
\hline Control & & $\begin{array}{c}98.66 \\
(83.46)\end{array}$ & $\begin{array}{c}98.34 \\
(82.48)\end{array}$ & $\begin{array}{c}98.50 \\
(82.97)\end{array}$ & & $\begin{array}{c}85.00 \\
(68.27)\end{array}$ & $\begin{array}{c}89.00 \\
(71.27)\end{array}$ & $\begin{array}{c}87.00 \\
(69.77)\end{array}$ & \\
\hline SE & & & & 1.24 & & & & 1.66 & \\
\hline $\mathrm{CD}(p=0.05 \%)$ & & & & 2.12 & & & & 2.84 & \\
\hline
\end{tabular}
hexaconazole which was followed by carbendazim treated 
plots exhibiting 63.95 and $57.86 \%$ disease control, respectively under natural epiphytotic conditions. Dimethomorph was found to manage the disease at the lowest potential level (31.47\%) having maximum disease severity 68.33 and $66.66 \%$ next to control (98.66 and 98.34\%), respectively during 2010 and 2011 crop seasons. Rest of the treatments exhibited intermediate level of disease severity. Under protected conditions, the disease severity in general was at a lower level than under natural conditions in all the treatments but as far as the efficacy of different fungicides was concerned, it followed almost similar pattern as under natural epiphytotic conditions. The mean disease severity pooled for two years was minimum $(16.50 \%)$ when the plots were sprayed with hexaconazole which was significantly followed by carbendazim (24.66\%). Maximum disease severity recorded and pooled for both years (46.51\%) was found in the plots sprayed with dimethomorph which was however significantly lower than the untreated check $(87.00 \%)$. Rest of the treatments showed intermediate level of disease severity.

As far as pod yield under natural conditions was concerned, it was found to be maximum $\left(3.175 \mathrm{~kg} \mathrm{plot}^{-1}\right)$ in the plots sprayed with hexaconazole being statistically at par with carbendazim $\left(2.967 \mathrm{~kg} \mathrm{plot}^{-1}\right)$ when it was pooled for two years. However, minimum pod yield during both the years $(1.159 \mathrm{~kg}$ plot $^{-1}$ ) was recorded in the untreated control plots, which was statistically at par with the plots sprayed with dimethomorph $\left(1.752 \mathrm{~kg} \mathrm{plot}^{-1}\right)$ during both the years. Rest of the fungicides tested exhibited intermediate level of pod yield under natural conditions (Table 2). Data presented in (Table 2). further reveal that under protected conditions, the pod yield was comparatively higher in all the treatments as compared to natural conditions. It was recorded to be maximum $\left(4.838 \mathrm{~kg} \mathrm{plot}^{-1}\right)$ in plots sprayed with hexaconazole which was statistically at par with that in plots sprayed with carbendazim $\left(4.450 \mathrm{~kg} \mathrm{plot}^{-1}\right)$. Minimum pod yield was recorded in untreated control plots $\left(1.850 \mathrm{~kg} \mathrm{plot}^{-1}\right)$.

During present investigations, the trials were conducted both under natural and protected conditions and it was found that the disease levels were comparatively higher under natural conditions as compared to protected conditions in all the treatments including untreated check. The higher disease levels in open conditions are attributed to heavy winds blowing in the region during the cropping season which help in fast dissemination of the pathogen. The results of fungicidal testing however revealed similar pattern under both conditions where hexaconazole was most effective followed by carbendazim while, dimethomorph was least effective in managing the disease, although the disease control levels were higher under protected conditions as compared to natural conditions. The pod yield was found to exhibit a direct correlation with the disease levels in the plants being more in the plots having lesser disease and vice versa. Ransom et al. (1991); Alam et al. (2007); Loganathan et al. (2011) have reported the role of
Table 2: Yield of pea as influenced by different fungicidal sprays under protected and natural conditions

\begin{tabular}{lcccccccc}
\hline Treatments & \multicolumn{3}{c}{$\begin{array}{c}\text { Average yield } \\
\left(\mathrm{kg} \mathrm{plot}^{-1}\right)\end{array}$} & & \multicolumn{2}{c}{$\begin{array}{c}\text { Average yield }\left(\mathrm{kg} \mathrm{plot}^{-1}\right) \\
\text { natural conditions }\end{array}$} & & \multicolumn{3}{c}{$\begin{array}{c}c \\
\text { under protected } \\
\text { conditions }\end{array}$} \\
\cline { 2 - 4 } \cline { 7 - 9 } & 2010 & 2011 & Pooled & & 2010 & 2011 & Pooled \\
\hline Kitazin & 2.150 & 2.143 & 2.146 & & 3.400 & 3.280 & 3.340 \\
Demethomorph & 1.653 & 1.850 & 1.752 & & 2.750 & 2.150 & 2.450 \\
Difenoconazole & 1.827 & 2.553 & 2.18 & & 4.200 & 3.900 & 4.050 \\
Hexaconazole & 3.100 & 3.250 & 3.175 & & 4.975 & 4.700 & 4.838 \\
Carbendazim & 2.883 & 3.050 & 2.967 & & 4.350 & 4.550 & 4.450 \\
Propiconazole & 2.717 & 2.150 & 2.434 & & 3.700 & 3.00 & 3.350 \\
Control & 1.200 & 1.117 & 1.159 & & 2.050 & 1.650 & 1.850 \\
SE & & & 0.260 & & & & 0.306 \\
$\mathrm{CD}(p=0.05 \%)$ & & & 0.445 & & & 0.526 \\
\hline
\end{tabular}

triazoles like tebuconazole, propiconazole and flusilazolein managing the pea powdery mildew and increasing the pod yields. Hexaconazole has been reported to be effective against pea powdery mildew by Gupta and Shyam (1998). Jarial and Sharma (2011) have also reported hexaconazole and carbendazim to be effective against the disease and increasing the pod yield and other yield parameters correspondingly. However, there are no reports in the literature regarding comparative studies of the disease management under natural and protected conditions, so these results cannot be compared with.

Apparent infection rates (r) were calculated in terms of unit $^{-1}$ day $^{-1}$ in different tested fungicides both the natural and protected conditions of dry temperate zones during both the years i.e. 2010 and 2011 which were further pooled. From (Table 3), it is revealed that under natural conditions, amongst the different fungicides tested pooled apparent infection rate was maximum $\left(0.12\right.$ unit $^{-1}$ day $\left.^{-1}\right)$ in plots treated with dimethiomorph, which was statistically at par with kitazin treated plots $\left(0.10\right.$ unit $^{-1}$ day $\left.^{-1}\right)$ while, minimum $\left(0.04\right.$ unit $^{-1}$ day $^{-1}$ ) apparent infection rate was recorded in plots sprayed with propiconazole which was statistically at par with rest all fungicide treatments. Apparent infection rate was statistically highest in untreated control plots $\left(0.38\right.$ unit $^{-1}$ day $\left.^{-1}\right)$ during both the years. However, under protected conditions in general, the pooled apparent infection rates were comparatively lower than under natural conditions. It was statistically at par in all the fungicidal treatments being maximum in plots sprayed with dimethomorph $\left(0.07\right.$ unit $^{-1}$ day $\left.^{-1}\right)$ and minimum (0.04 unit $^{-1}$ day $^{-1}$ ) in plots sprayed with propiconazole. However, in untreated control plots apparent infection rate was found to be statistically highest $\left(0.30\right.$ unit $^{-1}$ day $\left.^{-1}\right)$.

It is evident from these results that the apparent infection rates were comparatively higher under natural conditions as 


\begin{tabular}{|c|c|c|c|c|c|c|}
\hline \multirow[t]{2}{*}{ Treatments } & \multicolumn{3}{|c|}{$\begin{array}{c}\text { Apparent infection } \\
\text { rate }\left(\text { unit }^{-1} \text { day }^{-1} \text { ) }\right. \\
\text { under natural } \\
\text { conditions }\end{array}$} & \multicolumn{3}{|c|}{$\begin{array}{l}\text { Apparent infection } \\
\text { rate }\left(\text { unit }^{-1} \text { day }^{-1}\right) \\
\text { under protected } \\
\text { conditions }\end{array}$} \\
\hline & 2010 & 2011 & Pooled & 2010 & 2011 & Pooled \\
\hline Kitazin & 0.10 & 0.10 & 0.10 & 0.06 & 0.05 & 0.06 \\
\hline Demetho-morph & 0.12 & 0.11 & 0.12 & 0.08 & 0.07 & 0.08 \\
\hline Difenoconazole & 0.07 & 0.04 & 0.06 & 0.04 & 0.05 & 0.04 \\
\hline Hexaconazole & 0.076 & 0.05 & 0.06 & 0.05 & 0.05 & 0.05 \\
\hline Carbendazim & 0.05 & 0.05 & 0.05 & 0.05 & 0.06 & 0.05 \\
\hline Propiconazole & 0.04 & 0.04 & 0.04 & 0.03 & 0.05 & 0.04 \\
\hline Control & 0.38 & 0.38 & 0.38 & 0.29 & 0.31 & 0.30 \\
\hline SE & & & 0.019 & & & 0.025 \\
\hline $\mathrm{CD}(p=0.05 \%)$ & & & 0.033 & & & 0.043 \\
\hline
\end{tabular}

compared to protected conditions in all the treatments including untreated check except in cabendazim and propiconazole treated plots. This variation in the apparent rates of spread of disease can be attributed to the fact that under natural epiphytotic conditions, there are various factors which are affecting the initial inoculum and its further spread which is otherwise controlled under protected conditions. There are no records of such comparative investigations in the literature till date. However, Banyal (1994) recorded an apparent infection rate of 0.16 and 0.13 unit $^{-1}$ day $^{-1}$ in variety Lincoln during 199192 and 1992-93, respectively under subtropical conditions of the state while, Jarial and Sharma (2005) observed apparent infection rate of 0.06 to 0.27 unit $^{-1}$ day $^{-1}$ in different germplasm lines of pea. Comparatively higher infection rates in control plots during present studies under both the conditions can be attributed to the fact that the area of cultivation under studies falls in dry temperate zone of Himachal Pradesh where the climatic factors are more favourable for the growth of pathogen. Also, the crop was raised by broadcast method which increased the planting density and ultimately increasing the rate of spread of disease.

\section{Conclusion}

Hexaconazole was quite effective in managing the disease ultimately leading to increased pod yields under both natural and protected conditions. It was also found that the disease levels and apparent rates of infection were comparatively higher under natural epiphytotic conditions as compared to protected conditions. So, it can be concluded that if the crop is raised under polyhouses, the farmers can raise healthier crops and harvest more by applying effective chemicals.

\section{References}

Alam, M., Sadat, A., Hoque1, M.Z., Rashid, M.H., 2007.
Management of powdery mildew and rust diseases of garden pea using fungicides. International Journal of Sustainable Crop Production 2, 56-60.

Anonoymous, 2015. District Lahaul and Spiti: Geographical conditions. http://www.himachal.nic.in.

Banyal, D.K. 1994. Studies on powdery mildew of pea caused by Erysiphe pisi DC. PhD Thesis. HPKV, Palampur (HP), 80.

Gomez, K.A., Gomez, A.A., 1984. $2^{\text {nd }}$ Edition. Statistical Procedures for Agricultural Research. John Wiley and Sons, New York, 680.

Gupta, S.K., Shyam, K.R., 1998. Control of powdery mildew and rust of pea by fungicides. Indian Phytopathology $51,184-186$.

Jarial, K., Sharma, R.C. 2005. Management of powdery mildew of pea caused by Erysiphe pisi Syd. with chemicals. The Fungi- Diversity and Conservation in India, J.S Dargan, N.S Atri and G.S Dhingra (eds). Bishen Singh Mahendra Pal Singh, Dehradun, UA (INDIA), 273-277.

Jarial, K., Sharma, R.C., 2005. Screening of pea germplasm for resistance against powdery mildew. In: Integrated Plant Disease Management, R.C. Sharma and J.N. Sharma (Eds.), Scientific Publishers, Jodhpur, 121-126.

Jarial, K., Sharma, D., 2011. Efficacy of different fungicides on powdery mildew and yield parameters of pea. Plant Disease Research 26, 172.

Kapadia, H., 1999. Spiti: Adventures in the Trans-Himalaya. $2^{\text {nd }}$ Edition. Indus Publishing Company, New Delhi. ISBN 81-7387-093-4.

Kapoor, A.S., Sugha, S.K. 1995. Efficacy of fungicides in controlling powdery mildew (Erysiphe pisi) of pea (Pisum sativum) in field. Indian Journal of Agricultural Sciences 65, 771-773.

Kotasthane, S.R., 1975. Fungicidal control of powdery mildew of pea. Science and Culture 41, 450-452.

Loganathan, M., Vekttaravanappa, V, Saha, S., Rai, A.B. 2011. Fungicidal management of powdery mildew (Erysiphe polygoni) in pea. Vegetable Science 38, 121-122.

Munjal, R.L., Chenulu, V.V., Hora, T.S. 1963. Assessment of losses due to powdery mildew (Erysiphe polygoni DC.) on pea. Indian Phytopathology16, 268-270.

Ransom, L.M., Briens, R.G.O., Glass, R.J. 1991. Chemical control of powdery mildew in green peas. Australian Plant Pathology 20, 16-20.

Upadhyay, A.L., Gupta, P.P., 1994. Fungicidal evaluation against powdery mildew and rust of pea (Pisum sativum L.). Annals of Agricultural Research 15, 114-116.

Van der Plank, J.E., 1963. Plant Disease: Epidemics and Control. Academic Press, New York, 349.

Yawalkar, K.S., 1992. Vegetable Crops of India. $4^{\text {th }}$ edition. Agri-Horticultural Publishing House, Nagpur, 383. 